\title{
Selective mono-benzylation of methylene active compounds with dibenzyl carbonate: benzylation of phenol
}

\author{
Maurizio Selva, Carlos Alberto Marques and Pietro Tundo* \\ Dipartimento di Scienze Ambientali dell'Universita' di Venezia, Calle Larga Santa Marta 2137, 30123 Venezia, Italy
}

\begin{abstract}
Dibenzyl carbonate (DBzlC) has been used to benzylate phenylacetonitrile, benzyl phenylacetate and phenol. In refluxing $N, N$-dimethylformamide (DMF) as solvent, and in the presence of $\mathrm{K}_{2} \mathrm{CO}_{3}$ phenol yielded benzyl phenyl ether and phenylacetonitrile the monobenzylated compound 2,3-diphenylpropionitrile. Likewise, in refluxing $N, N$-diethylformamide (DEF), benzyl phenyl acetate gave the benzyl 2,3-diphenylpropionate. Selectivity in mono- $C$-benzyl derivatives was $98-99 \%$ at a conversion up to $90 \%$. Such unusually high selectivity is explained in terms of a mechanism involving, initially, carboxybenzylation followed by benzylation, rather than direct benzylation.
\end{abstract}

\section{Introduction}

Although direct $C$-alkylation of methylene active compounds, particularly arylacetonitriles and alkyl arylacetates, may be effected by several methods, alkyl halides and dialkyl sulfates are usually employed as the alkylating agents. ${ }^{1 a-l}$ However, these reactions have a general drawback in that they are poorly selective and give rise to mixtures of mono- and di-alkylated products. Better results can be achieved under phase-transfer catalysis (PTC) conditions ${ }^{2 a-e}$ even though, when reactive alkylating agents (e.g. methyl, allyl and benzyl halides) are used, mono-alkyl selectivity remains low. ${ }^{2 c \cdot e}$ For some compounds, other often more complicated, synthetic strategies have also been reported. ${ }^{1 h-i, 3 a-h}$

Recently, we reported that dialkyl carbonates [dimethyl (DMC) and diethyl (DEC) carbonate], once believed completely ineffective for alkylations, ${ }^{1 a}$ are, in fact, excellent and very selective. ${ }^{4 a-b}$ In particular, operating both under gasliquid phase-transfer catalysis (GL-PTC) ${ }^{5}$ and batch conditions, at high temperatures $\left(170-220^{\circ} \mathrm{C}\right)$, dialkyl carbonates allow very selective mono-alkylations of arylacetonitriles and alkyl arylacetates [eqn. (1)], the reactions occurring in the presence of a base (usually $\mathrm{K}_{2} \mathrm{CO}_{3}$ ).

$$
\begin{aligned}
& \underset{\mathbf{A r C H}}{\mathrm{ArCH}_{2} \mathrm{X}}+\mathrm{ROCO}_{2} \mathrm{R} \stackrel{\text { base }}{\underset{\mathrm{ArCH}}{\mathrm{Ar}}(\mathrm{R}) \mathrm{X}}+\mathrm{ROH}+\mathrm{CO}_{2} \\
& \mathrm{X}=\mathrm{CN}(\mathbf{2 a}), \mathrm{CO}_{2} \mathrm{R}(\mathbf{2 b}) ; \mathrm{R}=\mathrm{Me}, \mathrm{Et}
\end{aligned}
$$

Typically, despite the high temperatures used, monoalkylation selectivity is $>99.5 \%$ (at complete conversion). ${ }^{6 a-c}$

Under these conditions, DMC is also very effective in the $O$-alkylation of phenols, to give the corresponding anisoles. ${ }^{4 a, 7}$

Alkylation by dialkyl carbonates is characterized by the absence of waste and a complete recycling of the co-product alcohol; these features encouraged us to explore the applicability of this new synthetic method.

\section{Results}

Here we report the highly selective mono- $C$-benzylation of phenylacetonitrile and benzyl phenyl acetate with dibenzyl carbonate (DBzlC) [eqn. (2)].

$$
\begin{aligned}
& \mathrm{PhCH}_{2} \mathrm{X}+\mathrm{PhCH}_{2} \mathrm{OCO}_{2} \mathrm{CH}_{2} \mathrm{Ph} \stackrel{\mathrm{K}_{2} \mathrm{CO}_{3}}{\longrightarrow} \\
& \text { la } \\
& \begin{array}{l}
\underset{\mathbf{P h C H}}{\mathbf{3}}\left(\mathrm{CH}_{2} \mathrm{Ph}\right) \mathrm{X}+\mathrm{PhCH}_{2} \mathrm{OH}+\mathrm{CO}_{2} \\
\mathrm{X}=\mathrm{CN}(3 \mathrm{a}), \mathrm{CO}_{2} \mathrm{CH}_{2} \mathrm{Ph}(\mathbf{3 b})
\end{array}
\end{aligned}
$$

At the same time, we report that DBzlC has proved to be a good $O$-alkylating agent of phenol giving the corresponding benzyl phenyl ether [eqn. (3)].

$$
\underset{4}{\mathrm{PhOH}+\mathrm{PhCH}_{2} \mathrm{OCO}_{2} \mathrm{PhCH}_{2} \stackrel{\mathrm{K}_{2} \mathrm{CO}_{3}}{\longrightarrow}} \underset{\mathrm{PhOCH}_{2} \mathrm{Ph}+\mathrm{PhCH}_{2} \mathrm{OH}+\mathrm{CO}_{2}}{\longrightarrow}
$$

Both $C$ - and $O$-benzylations were performed under batch conditions operating at $140-180^{\circ} \mathrm{C}$, in a variety of solvents $[N, N$-dimethylformamide (DMF), $N, N$-diethylformamide (DEF), triethylene glycol dimethyl ether (Triglyme), polyethylene glycol 250 (PEG 250), xylene] and in the presence of a $2 \mathrm{~mol}$ equiv. of $\mathrm{K}_{2} \mathrm{CO}_{3}$. All reactions were carried out under $\mathrm{N}_{2}$ (atmospheric pressure) in order to prevent the oxidation of the co-product benzyl alcohol to benzaldehyde or other products through Knoevenagel condensation with the reagent substrate $\left[\right.$ i.e. $\mathrm{PhC}(\mathrm{CN})=\mathrm{CHPh}$, see Tables 1-2]. ${ }^{1 f, 3 b} C$ - Benzylation of phenylacetonitrile was the more extensively studied reaction.

Table 1 reports the results obtained in the reaction of phenylacetonitrile with $\mathrm{DBzlC}$ in the presence of different solvents. Selectivity in the mono- $C$-benzyl derivative $(2,3-$ diphenylpropionitrile, 2a) was always very high (98-99\%) at conversions up to $90 \%$.

Aprotic, polar solvents (DEF, DMF) used at the reflux temperature (155 and $177^{\circ} \mathrm{C}$, respectively), gave the fastest reactions (entries 1-2). Despite the well-known properties of polyethylene glycols as anion activators, ${ }^{8}$ the use of Triglyme and PEG 250 resulted in longer reaction times, even operating at $180^{\circ} \mathrm{C}$ (entries 3-6). Xylene completely depressed the reaction (entry 7$)$ : thus, at the reflux temperature $\left(140^{\circ} \mathrm{C}\right.$ ), almost no reaction occurred after $3.0 \mathrm{~h}$ while at the same temperature, but in DMF, conversion was $43.3 \%$ after $5.0 \mathrm{~h}$ (entry 1, Table 2).

Table 2 reports the effect of the reaction temperature and the substrate/alkylating agent molar ratio for the benzylation of phenylacetonitrile. Also, a comparison between DBzlC and $\mathrm{PhCH}_{2} \mathrm{Cl}$ as alkylating agents is shown. Operating at $120^{\circ} \mathrm{C}$ in DMF, only $5 \%$ conversion was observed after 3.0 h (entry 1 ); higher temperatures, up to $140^{\circ} \mathrm{C}$, were required for the reaction to occur at an appreciable rate (entries 1,2). The reaction rate could also be increased by decreasing the substrate/DBzlC molar ratio (entries 2-4), this behaviour appearing even when other solvents were used (compare entries 3,4 and 5,6, Table 1).

The comparison between $\mathrm{DBzlC}$ and $\mathrm{PhCH}_{2} \mathrm{Cl}$ was made both in DMF (entries 5,6) and under PTC conditions (toluene 
Table 1 Benzylation of phenylacetonitrile with dibenzyl carbonate in the presence of different solvents ${ }^{a}$

\begin{tabular}{|c|c|c|c|c|c|c|c|c|c|}
\hline \multirow[b]{2}{*}{ Entry } & \multirow[b]{2}{*}{ Solvent } & \multirow[b]{2}{*}{$\begin{array}{l}\text { Reaction } \\
\text { time }(t / \mathrm{h})\end{array}$} & \multirow[b]{2}{*}{$\begin{array}{l}\text { Temp. } \\
\left(T /{ }^{\circ} \mathrm{C}\right)\end{array}$} & \multirow[b]{2}{*}{$\begin{array}{l}\text { Molar ratio } \\
\text { (Sub./Alkyl.) }\end{array}$} & \multirow[b]{2}{*}{$\begin{array}{l}\text { Conv'n } \\
(\%)\end{array}$} & \multirow[b]{2}{*}{$\begin{array}{l}\text { Selectivity }{ }^{c} \\
(\%)\end{array}$} & \multicolumn{3}{|l|}{ Products $(\%)^{d}$} \\
\hline & & & & & & & $\mathrm{PhCH}(\mathrm{R}) \mathrm{CN}$ & $\begin{array}{l}\mathrm{PhC}\left(\mathrm{R}_{2}\right) \mathrm{CN} \\
\left(\mathrm{R}=\mathrm{CH}_{2} \mathrm{Ph}\right)\end{array}$ & $\mathrm{PhC}(\mathrm{CN})=\mathrm{CHPh}$ \\
\hline \multirow[t]{2}{*}{1} & DEF & 1.25 & $177^{e}$ & $1: 1.1$ & 91.7 & 99.1 & 88.2 & 0.8 & 2.7 \\
\hline & & 1.5 & 177 & $1: 1.1$ & 98.5 & 97.9 & 93.6 & 2.0 & 2.9 \\
\hline 2 & DMF & 4.0 & $155^{e}$ & $1: 1.1$ & 86.0 & 99.2 & 83.5 & 0.6 & 1.9 \\
\hline \multirow[t]{2}{*}{3} & Triglyme & 2.0 & 160 & $1: 1.1$ & 8.0 & & & & \\
\hline & & 6.0 & 180 & $1: 1.1$ & 62.2 & 100 & 60.0 & - & 2.2 \\
\hline 4 & Triglyme & 8.25 & 180 & $1: 3.0$ & 93.1 & 99.5 & 90.8 & 0.5 & 1.8 \\
\hline 5 & PEG 250 & 7.25 & 180 & $1: 1.1$ & 47.5 & 100 & 45.0 & - & 2.5 \\
\hline 6 & PEG-250 & 7.0 & 180 & $1: 3.0$ & 83.0 & 100 & 75.5 & - & 7.5 \\
\hline \multirow[t]{3}{*}{7} & Xylene $^{f}$ & 3.0 & 90 & $1: 1.1$ & - & & & & \\
\hline & & 3.0 & 110 & $1: 1.1$ & - & & & & \\
\hline & & 3.0 & $140^{e}$ & & 1.8 & & 0.8 & - & 1.0 \\
\hline
\end{tabular}

a 2 mol equiv. of $\mathrm{K}_{2} \mathrm{CO}_{3}$ were used in all reactions. ${ }^{b} \mathrm{PhCH}_{2} \mathrm{CN} / \mathrm{DBzlC}$ molar ratio. ${ }^{c}$ Selectivity is defined as: $[\mathrm{PhCH}(\mathrm{R}) \mathrm{CN}] /\{[\mathrm{PhCH}(\mathrm{R}) \mathrm{CN}]+$ $\left.\left[\mathrm{PhC}\left(\mathrm{R}_{2}\right) \mathrm{CN}\right]\right\} \times 100 ; \mathrm{R}=\mathrm{CH}_{2} \mathrm{Ph}$. ${ }^{d}$ Other by-products were $\mathrm{PhCH}_{2} \mathrm{OCH}_{2} \mathrm{Ph}, \mathrm{PhCOOCH}{ }_{2} \mathrm{Ph}, \mathrm{PhCH}_{2} \mathrm{COPh}$ whose total amount (referred to the main product, $\mathrm{PhCH}(\mathrm{R}) \mathrm{CN}$ ) was $<1 \%$ (entries $1-4$ ) and $\leqslant 7 \%$ (entries 5-6). ${ }^{e}$ Reflux temperature of the solvent. ${ }^{f}$ Aliquat $336(2 \%$ molar with respect to the substrate) was used as phase-transfer catalyst.

Table 2 Benzylation of phenylacetonitrile at different temperatures and molar ratios (substrate to alkylating agent)

\begin{tabular}{|c|c|c|c|c|c|c|c|c|c|c|}
\hline \multirow[b]{2}{*}{ Entry* } & \multirow[b]{2}{*}{ Solvent } & \multirow[b]{2}{*}{$\begin{array}{l}\text { Reaction } \\
\text { time }(t / \mathrm{h})\end{array}$} & \multirow[b]{2}{*}{$\begin{array}{l}\text { Temp. } \\
\left(T /{ }^{\circ} \mathrm{C}\right)\end{array}$} & \multirow[b]{2}{*}{$\begin{array}{l}\text { Alkylating } \\
\text { agent }\end{array}$} & \multirow[b]{2}{*}{$\begin{array}{l}\text { Molar ratio } \\
\text { (Sub./Alkyl.) }\end{array}$} & \multirow[b]{2}{*}{$\begin{array}{l}\text { Conv'n } \\
(\%)\end{array}$} & \multirow[b]{2}{*}{$\begin{array}{l}\text { Selectivity }{ }^{a} \\
(\%)\end{array}$} & \multicolumn{3}{|l|}{ Products $(\%)^{b}$} \\
\hline & & & & & & & & $\mathrm{PhCH}(\mathrm{R}) \mathrm{CN}$ & $\begin{array}{l}\mathrm{PhC}\left(\mathrm{R}_{2}\right) \mathrm{CN} \\
\left(\mathrm{R}=\mathrm{CH}_{2} \mathrm{Ph}\right)\end{array}$ & $\begin{array}{l}\mathrm{PhC}(\mathrm{CN})= \\
\mathrm{CHPh}\end{array}$ \\
\hline \multirow[t]{2}{*}{1} & \multirow[t]{2}{*}{ DMF } & 3.0 & 120 & DBzlC & $1: 1.1$ & 4.8 & 100 & & & \\
\hline & & 5.0 & 140 & DBzlC & $1: 1.1$ & 43.3 & 100 & 41.7 & - & 1.6 \\
\hline 2 & DMF & 4.0 & 155 & DBzlC & $1: 1.1$ & 86.0 & 99.2 & 83.5 & 0.6 & 1.9 \\
\hline 3 & $\mathrm{DMF}$ & 2.5 & 155 & DBzlC & $1: 1.5$ & 91.7 & 99.1 & 87.7 & 0.8 & 3.2 \\
\hline \multirow[t]{2}{*}{4} & \multirow{2}{*}{ DMF } & 2.25 & 155 & DBzlC & $1: 3.0$ & 95.6 & 98.4 & 91.7 & 1.5 & 2.4 \\
\hline & & 2.75 & 155 & DBzlC & $1: 3.0$ & 100 & 95.1 & 92.6 & 4.7 & 2.7 \\
\hline 5 & DMF & 6.0 & 40 & $\mathrm{PhCH}_{2} \mathrm{Cl}$ & $1: 0.8$ & 48.1 & 84.9 & 40.6 & 7.2 & 0.3 \\
\hline 6 & DMF & 4.0 & 80 & $\mathrm{PhCH}_{2} \mathrm{Cl}$ & $1: 1.5$ & 82.3 & 64.9 & 52.1 & 28.2 & 2.0 \\
\hline \multirow[t]{2}{*}{7} & \multirow[t]{2}{*}{ Toluene $^{c}$} & 4.0 & $\mathrm{rt}$ & $\mathrm{PhCH}_{2} \mathrm{Cl}$ & $1: 1$ & 18.2 & 93.4 & 17.0 & 1.2 & - \\
\hline & & 19.5 & $\mathrm{rt}$ & $\mathrm{PhCH}_{2} \mathrm{Cl}$ & $1: 1$ & 81.1 & 53.1 & 41.1 & 36.3 & 3.7 \\
\hline
\end{tabular}

* Entries 1-6: 2 mol equiv. of $\mathrm{K}_{2} \mathrm{CO}_{3}$ were used. a The selectivity is defined as: $\left[\mathrm{PhCH}(\mathrm{R}) \mathrm{CN} /\left\{[\mathrm{PhCH}(\mathrm{R}) \mathrm{CN}]+\left[\mathrm{PhC}\left(\mathrm{R}_{2}\right) \mathrm{CN}\right]\right\} \times 100 ; \mathrm{R}=\right.$

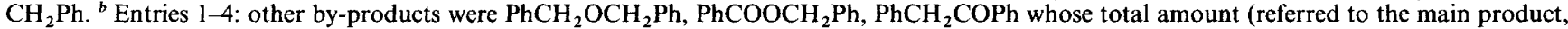
$\mathrm{PhCH}(\mathrm{R}) \mathrm{CN})$ was $<1 \%$; entries 5-8: other by-products were $\leqslant 5 \%$ [total amount referred to the main product, PhCH(R)CN]. ${ }^{c} \mathrm{Liquid}-\mathrm{liquid}$ phase-transfer catalysis (LL-PTC) conditions were used: $50 \%$ aq. $\mathrm{KOH}\left(11.5 \mathrm{~cm}^{3} / \mathrm{g}\right.$ substrate) and aliquat $336(2 \%$ molar with respect to substrate).

solvent; entry 7, see Experimental section for details). In the case of $\mathrm{PhCH}_{2} \mathrm{Cl}$, the mono-benzylation selectivity was in the range $85-53 \%$ at conversions of $52-81 \%$. There was no improvement with a decrease in the alkylating agent/substrate molar ratio (from 1.5 to 0.8 ) or a lowering of the reaction temperature. On the other hand, benzylation of phenylacetonitrile by $\mathrm{PhCH}_{2} \mathrm{Cl}$ under PTC conditions, was reported to be mono-benzyl selective only in the range $75-85 \%$ at conversions of $40-60 \% \%^{2 e}$

Table 3 reports the benzylation of different substrates by $\mathrm{DBzlC}$ in DMF and DEF solvents. At $155^{\circ} \mathrm{C}, O$-benzylation occurred more rapidly than $C$-benzylation. In particular, with a $\mathrm{DBzlC} /$ substrate of 1.1 the conversion of phenol was $93.5 \%$ after $2.0 \mathrm{~h}$ (entry 2 ) while, under the same reaction conditions, for phenylacetonitrile it was $90 \%$ after $6.0 \mathrm{~h}$ (entry 1$). \dagger$

Benzyl phenyl acetate reacted more slowly than phenylacetonitrile (entry 3 ) and both a higher DBzlC/substrate molar ratio $(1.5: 1)$ and a higher reaction temperature $\left(177^{\circ} \mathrm{C}\right.$,

$\dagger$ Comparison of entry 2 of Table 1 and entry 1 of Table 3, suggests that the difference in the reaction times for the benzylation of $\mathrm{PhCH}_{2} \mathrm{CN}$ (4 and $6 \mathrm{~h}$, respectively) is probably due to the very different amounts of the reacting substrates $(0.5 \mathrm{~g}$ and $2.5 \mathrm{~g}$, respectively). The results given in Table 3 allow a fairer comparison since comparable quantities of reagents are considered. refluxing DEF) were necessary to ensure comparable reaction times; thus, a conversion of $92 \%$ was reached after $4.5 \mathrm{~h}$ (entry $5)$. Similar behaviour was also observed in the methylation of arylacetic esters by DMC: ${ }^{6 c}$ methyl arylacetates required both higher reaction times and temperatures $\left(\geqslant 220^{\circ} \mathrm{C}\right)$ with respect to arylacetonitriles, to give the corresponding mono-methyl derivatives.

\section{Discussion}

At high temperatures $\left(140-180^{\circ} \mathrm{C}\right), \mathrm{DBzlC}$ has proved to be an efficient benzylating agent of phenol and $\mathrm{CH}_{2}$ acidic compounds, behaviour in which it strongly resembles DMC; nevertheless, methylation by DMC (occurring at $170-220^{\circ} \mathrm{C}$ ) necessarily requires an autoclave system while the higher boiling point of DBzlC allows benzylation to occur at atmospheric pressure. Since a solvent is used DBzlC can be employed in only a slight excess with respect to the reagent substrate; the best solvents have proved to be DMF and DEF (Tables 1-3).

Although the use of $\mathrm{K}_{2} \mathrm{CO}_{3}$ and DMF, in the alkylation of methylene-active compounds, is well established ${ }^{9 a, b}$ selective mono-alkylation with reactive alkyl halides under such conditions has been elusive. Thus, in DMF-KOH significant amounts $(26 \%)$ of dialkyl derivative were obtained in the 
Table 3 Benzylation of different substrates by dibenzyl carbonate

\begin{tabular}{|c|c|c|c|c|c|c|c|c|}
\hline Entry* & Substrate & Solvent & $\begin{array}{l}\text { Reaction } \\
\text { time }(t / \mathrm{h})\end{array}$ & $\begin{array}{l}\text { Temp. } \\
\left(T /{ }^{\circ} \mathrm{C}\right)\end{array}$ & $\begin{array}{l}\text { Molar ratio } \\
\text { (Sub/DBzlC) }\end{array}$ & $\begin{array}{l}\text { Convn } .^{a} \\
(\%)\end{array}$ & $\begin{array}{l}\text { Product } \\
\left(\mathrm{R}=\mathrm{CH}_{2} \mathrm{Ph}\right)\end{array}$ & $\begin{array}{l}\text { Yield }^{b} \\
(\%)\end{array}$ \\
\hline 1 & $\mathrm{PhCH}_{2} \mathrm{CN}$ & DMF & 6.0 & 155 & $1: 1.1$ & 90.0 & $\mathrm{PhCH}(\mathrm{R}) \mathrm{CN}$ & $82.0^{c}$ \\
\hline 2 & $\mathrm{PhOH}$ & DMF & 2.0 & 155 & $1: 1.1$ & 93.5 & $\mathrm{PhOR}^{d}$ & $80.0^{e}$ \\
\hline 3 & $\mathrm{PhCH}_{2} \mathrm{CO}_{2} \mathrm{CH}_{2} \mathrm{Ph}$ & DMF & 11.0 & 155 & $1: 1.1$ & 58.8 & $\mathrm{PhCH}(\mathrm{R}) \mathrm{CO}_{2} \mathrm{CH}_{2} \mathrm{Ph}$ & \\
\hline 4 & $\mathrm{PhCH}_{2} \mathrm{CO}_{2} \mathrm{CH}_{2} \mathrm{Ph}$ & DEF & 5.0 & 177 & $1: 1.3$ & 87.6 & $\mathrm{PhCH}(\mathrm{R}) \mathrm{CO}_{2} \mathrm{CH}_{2} \mathrm{Ph}^{d}$ & \\
\hline 5 & $\mathrm{PhCH}_{2} \mathrm{CO}_{2} \mathrm{CH}_{2} \mathrm{Ph}$ & DEF & 4.5 & 177 & $1: 1.5$ & 92.1 & $\mathrm{PhCH}(\mathrm{R}) \mathrm{CO}_{2} \mathrm{CH}_{2} \mathrm{Ph}^{d}$ & $83.0^{c}$ \\
\hline
\end{tabular}

* 2 mol equiv. of $\mathrm{K}_{2} \mathrm{CO}_{3}$ were used in all reactions. ${ }^{a}$ Determined by GC. ${ }^{b}$ Yields based on isolated products. ${ }^{c}$ Starting from $2.5 \mathrm{~g}$ of substrate. ${ }^{d}$ Other by-products were $\leqslant 4 \%$ (entry 2 ) and $\leqslant 6 \%$ (entry 5): total amount is referred to $\mathrm{PhOR}$ and $\mathrm{PhCH}(\mathrm{R}) \mathrm{CO}_{2} \mathrm{CH}_{2} \mathrm{Ph}$, respectively. ${ }^{e} \mathrm{Starting}$ from $2.0 \mathrm{~g}$ of substrate.

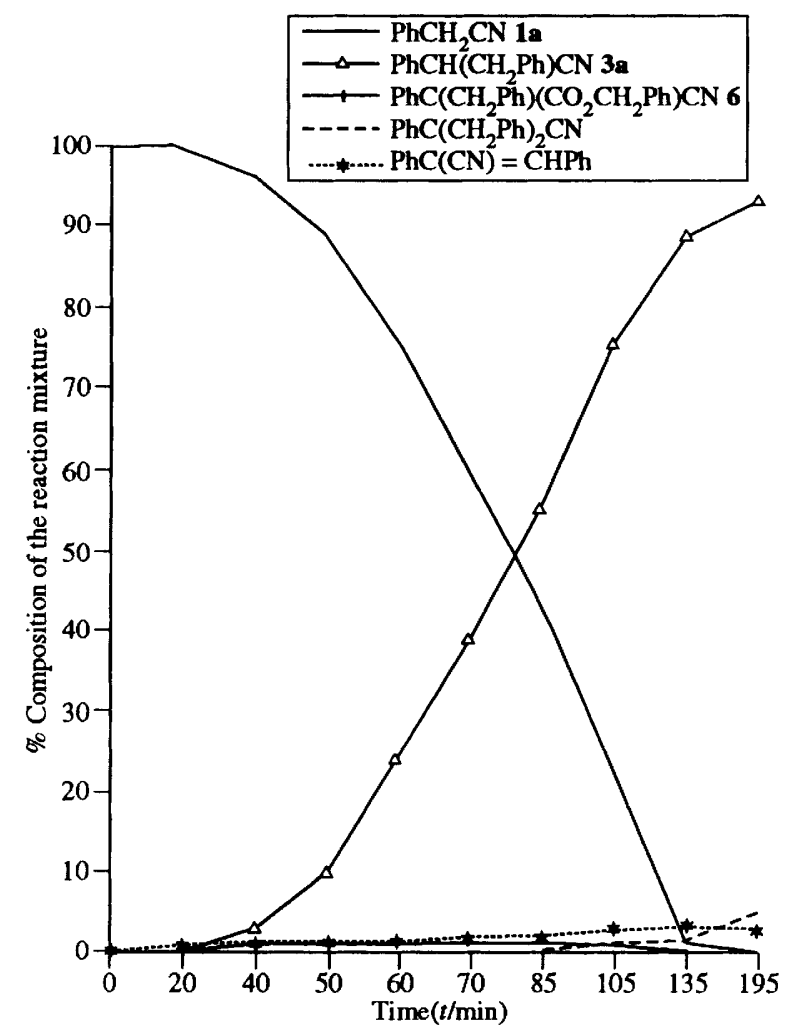

Fig. 1 The reaction of phenylacetonitrile with dibenzyl carbonate in DMF

benzylation of phenylacetonitrile by benzyl chloride. ${ }^{10}$ In contrast, we obtained a high degree of mono-benzylation selectivity by use of DBzlC. Probably this reaction proceeds according to the mechanism already described for $\mathrm{DMC},{ }^{6 a-c}$ since in the benzylation of phenylacetonitrile by DbzlC an intermediate, 2-benzyl-2-carboxybenzylphenylacetonitrile, was shown to be present (by GC/MS).

Fig. 1 illustrates the course and Scheme 1 the proposed mechanism for a reaction employing $\mathrm{PhCH}_{2} \mathrm{CN}, \mathrm{DBzlC}$ and $\mathrm{K}_{2} \mathrm{CO}_{3}(1: 1.5: 2 \mathrm{~mol}$ ratio) in refluxing DMF.

Although the concentration of the intermediate 5 was too low for it to be detected, its formation is proposed on the basis that in the reaction of arylacetonitriles with DMC similar behaviour was noted. In fact, the corresponding carboxymethyl intermediates $\mathrm{ArCH}\left(\mathrm{CO}_{2} \mathrm{Me}\right) \mathrm{CN}$ were observed only during the methylation of $o$-tolyacetonitrile and $m$-carboxymethylphenylacetonitrile by DMC. ${ }^{6 c}$

Since the carboxybenzyl group of the intermediate 5 has a protective function whilst at the same time increasing the acidity of the remaining hydrogen over that in the starting $\mathrm{PhCH}_{2} \mathrm{CN}$, subsequent benzylation gives the observed intermediate 6. Finally, the decarboxybenzylation of 6 gives the

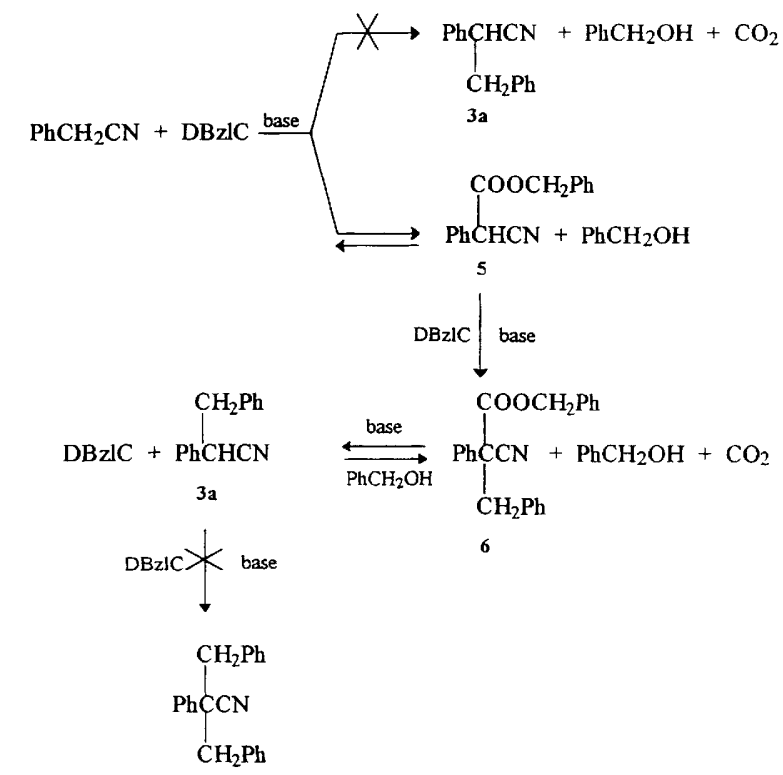

Scheme 1

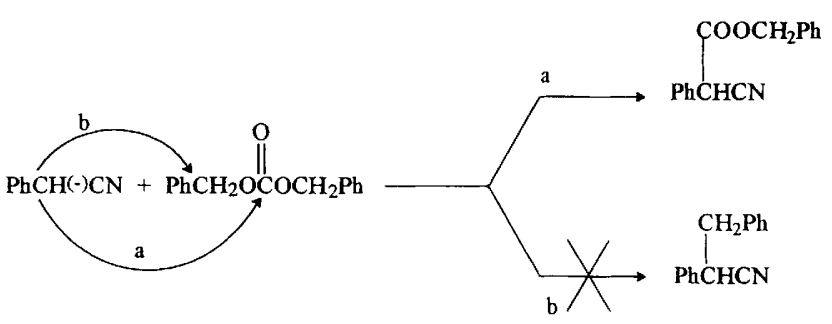

Fig. 2(a) $\quad \mathrm{B}_{\mathrm{Ac}} 2$ mechanism (path a). $\mathrm{B}_{\mathrm{A} \mid} 2$ mechanism (path b)

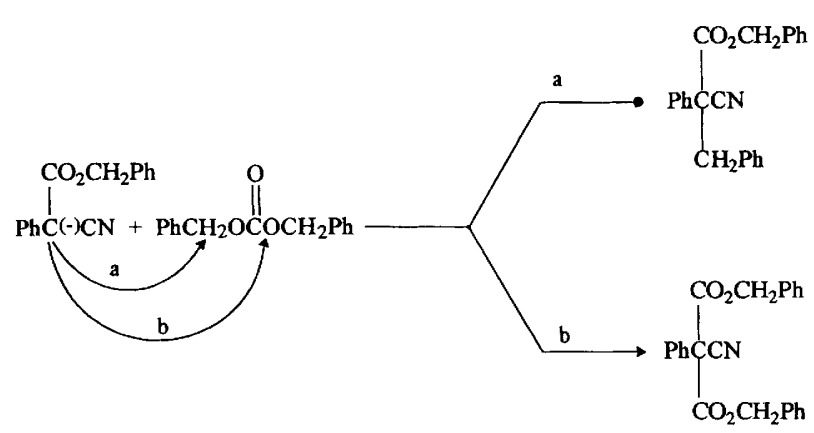

Fig. 2(b)

mono-benzyl derivative 3a. Selectivity in the overall reaction may be explained in terms of attack by the anion $\mathrm{Ph}(\mathrm{CN}) \mathrm{CH}^{-}$ 
on the acyl carbon of DBzlC (via a $\mathrm{B}_{\mathrm{Ac}} 2$ mechanism) and not the benzyl carbon [Fig. 2(a)].

Instead, the second possible anionic species, $\mathrm{PhC}^{-}\left(\mathrm{CO}_{2} \mathrm{CH}_{2}-\right.$ $\mathrm{Ph}) \mathrm{CN}$ attacks both the alkyl (via a $\mathrm{B}_{\mathrm{Al}} 2$ mechanism) and the acyl carbon of DBzlC; however, being an equilibrium reaction, the attack to the acyl carbon to produce the likely intermediate $\mathrm{PhC}\left(\mathrm{CO}_{2} \mathrm{CH}_{2}\right)_{2} \mathrm{CN}$ cannot effect the selectivity [Fig. 2(b)].

The driving force for the mono-benzylation is the nonequilibrium reaction following the $\mathrm{B}_{\mathrm{A} 1} 2$ mechanism [path (a) in Fig. 2(b)].

As in the alkylation by DMC, DBzlC does not produce an inorganic salt (as alkyl halides do) and the base can be used in catalytic amounts; these features make such alkylations of interest from an environmental point of view.

\section{Conclusion}

DBzlC seems to be particularly attractive as a selective benzylating agent since the reaction conditions are simple and the selectivity high (at almost complete conversion); the latter makes for easy separation of the mono- $C$-alkyl derivative from the reaction mixture.

At present, the reasons for such selectivity are not well understood; in particular, the reason why benzylation with DBzlC occurs only via the carboxybenzyl intermediate (5 in Scheme I) with no direct benzylation. The softness and the hardness of the involved anions and the acid--base equilibria in Scheme 1, are likely to influence the reaction. Further applications of DBzIC are being studied.

\section{Experimental}

\section{General}

All compounds were ACS grade and were employed without further purification. Melting points were determined on a Buchi 535 melting-point apparatus and are uncorrected. ${ }^{1} \mathbf{H}$ NMR spectra were recorded on Varian Unity $400(400 \mathrm{MHz})$ spectrometers using $\mathrm{CDCl}_{3}$ with TMS as the internal standard. $J$ Values are recorded in $\mathrm{Hz}$. GC analyses were performed on a Varian GC 3300 using a fused silica capillary column (30 $\mathrm{m} \times 0.25 \mathrm{~mm}$ ) with DB5 as liquid phase (film thickness 0.25 $\mathrm{mm}$ ). GC/MS analyses were performed on a HP 5971 mass detector coupled to a HP 5890 gas chromatograph fitted with a $30 \mathrm{~m} \times 0.25 \mathrm{~mm}$, DB5 capillary column.

\section{Dibenzyl carbonate 7}

A stirred mixture of benzyl alcohol $(20.0 \mathrm{~g}, 0.18 \mathrm{~mol})$, dimethyl carbonate $\left(46.7 \mathrm{~cm}^{3}, 0.55 \mathrm{~mol}\right)$ and $\mathrm{K}_{2} \mathrm{CO}_{3}(25.6 \mathrm{~g}, 0.18 \mathrm{~mol})$ was heated at $85^{\circ} \mathrm{C}$, in a round-bottomed flask fitted with a Liebig condenser for $24 \mathrm{~h}$, after which the excess of dimethyl carbonate was removed by distillation under reduced pressure. Benzyl alcohol $(20.0 \mathrm{~g}, 0.18 \mathrm{~mol})$ was added to the residue and the mixture heated to $120^{\circ} \mathrm{C}$; the reaction was performed under reduced pressure $(20 \mathrm{mmHg})$, in order to ensure removal of methanol. After $6 \mathrm{~h}$, the mixture was cooled to room temperature and the $\mathrm{K}_{2} \mathrm{CO}_{3}$ filtered off and washed with diethyl ether $\left(100 \mathrm{~cm}^{3}\right)$. The combined filtrate and washings were concentrated after which the excess of benzyl alcohol was removed by distillation under reduced pressure to give the title compound $7(27.7 \mathrm{~g}, 62 \%)$ as a pale yellow liquid ${ }^{11 a-e}(95.6 \%$ by GC) which, with time, slowly crystallized. It was recrystallized from pentane to give a white solid, $\mathrm{mp} 27.3-29.1^{\circ} \mathrm{C}$ (lit., ${ }^{11 e} \mathrm{bp}$ $\left.197-198{ }^{\circ} \mathrm{C} / 12 \mathrm{mmHg}\right) ; \delta_{\mathrm{H}} 5.17\left(\mathrm{~s}, 4 \mathrm{H}, 2 \mathrm{CH}_{2}\right)$ and $7.32-7.38$ (m, $10 \mathrm{H}, 2 \mathrm{Ph})$.

\section{Benzyl phenylacetate 8}

A mixture of phenylacetic acid $(10.0 \mathrm{~g}, 73 \mathrm{mmol})$, benzyl alcohol $(20.0 \mathrm{~g}, 180 \mathrm{mmol})$ and toluene-p-sulfonic acid monohydrate
$(1.8 \mathrm{~g}, 9.1 \mathrm{mmol})$ was set aside at room temperature for $15 \mathrm{~h}$ after which a solution of $\mathrm{KHCO}_{3}(2.5 \mathrm{~g}, 29 \mathrm{mmol})$ in water (20 $\mathrm{cm}^{3}$ ) was added to it with stirring. The mixture was extracted with diethyl ether $\left(3 \times 30 \mathrm{~cm}^{3}\right)$ and the combined extracts were dried $\left(\mathrm{Na}_{2} \mathrm{SO}_{4}\right)$ and distilled through a Vigreux column to afford the title compound $8(12.6 \mathrm{~g}, 76 \%)$, bp $106-109^{\circ} \mathrm{C} / 0.07$ $\mathrm{mmHg}$ (purity $>99^{\circ}$ by GC lit., ${ }^{12}$ bp $137-140{ }^{\circ} \mathrm{C} / 1.5 \mathrm{mmHg}$ ); $\delta_{\mathrm{H}} 3.65\left(\mathrm{~s}, 2 \mathrm{H}, \mathrm{CH}_{2}\right), 5.12\left(\mathrm{~s}, 2 \mathrm{H}, \mathrm{CH}_{2}\right)$ and $7.28-7.31(\mathrm{~m}, 10 \mathrm{H}$, $2 \mathrm{Ph}) ; \mathrm{m} / z 226\left(\mathrm{M}^{+}, 10 \%\right), 92(17), 91$ (100), 77 (6), 65 (28) and $51(8)$.

\section{Benzylations: general procedure}

The reactions were carried out by charging a 3-necked, roundbottomed flask, equipped with a condenser, a stop-cock and a glass screw-capped tube (fitted with a rubber silicon septum) used for sample withdrawal, with the substrate, DBzlC (or $\left.\mathrm{PhCH}_{2} \mathrm{Cl}\right)(1.1-3.0 \mathrm{~mol}$ equiv. with respect to the substrate, see Tables 1-3), $\mathrm{K}_{2} \mathrm{CO}_{3}$ (2 mol equiv. with respect to the substrate) and solvent ( $\sim 12 \mathrm{~cm}^{3} \mathrm{~g}^{-1}$ substrate; see Table 1 for details). The flask was flushed both before and during the reaction with nitrogen. The reaction mixtures, magnetically stirred and heated in an oil-bath to the appropriate temperature, were analysed by GC.

In order both to facilitate the separation of the products 3a and 9 and to evaluate their yields, the slight excess of DBzlC present at the end of the reaction was hydrolysed at room temperature, with $5 \%$ aq. $\mathrm{NaOH}$.

\section{Benzyl phenyl ether 9}

A mixture of phenol $(2.0 \mathrm{~g}, 22 \mathrm{mmol}), \mathrm{DBzlC}(5.7 \mathrm{~g}, 23 \mathrm{mmol})$, $\mathrm{K}_{2} \mathrm{CO}_{3}(5.9 \mathrm{~g}, 42 \mathrm{mmol})$ and DMF $\left(25 \mathrm{~cm}^{3}\right)$ was heated for $2 \mathrm{~h}$ under reflux $\left(\sim 155^{\circ} \mathrm{C}\right)$, as described above. After the mixture had been cooled to room temperature it was treated with $5 \%$ aq $\mathrm{NaOH}\left(5 \mathrm{~cm}^{3}\right)$, stirred for $30 \mathrm{~min}$, diluted with water $\left(100 \mathrm{~cm}^{3}\right)$ and extracted with diethyl ether $\left(3 \times 40 \mathrm{~cm}^{3}\right)$. The combined extracts were dried $\left(\mathrm{Na}_{2} \mathrm{SO}_{4}\right)$ after which the benzyl alcohol present was removed by distillation under reduced pressure to leave the title compound $9(3.1 \mathrm{~g}, 79.5 \%)$ as a liquid (purity $92 \%$ by GC) which rapidly crystallized. It was recrystallized from pentane to give white needles, $\mathrm{mp} 38.4-39.0$ (lit., ${ }^{13 a} \mathrm{mp} 40^{\circ} \mathrm{C}$ ); $\delta_{\mathrm{H}} 5.06\left(\mathrm{~s}, 2 \mathrm{H}, \mathrm{CH}_{2}\right)$ and $6.96-7.45(\mathrm{~m}, 10 \mathrm{H}, 2 \mathrm{Ph})$.

\section{2,3-Diphenylpropionitrile 3a}

A mixture of $\mathrm{PhCH}_{2} \mathrm{CN}(2.5 \mathrm{~g}, 21 \mathrm{mmol}), \mathrm{DBzlC}(5.7 \mathrm{~g}, 23$ $\mathrm{mmol}), \mathrm{K}_{2} \mathrm{CO}_{3}(5.9 \mathrm{~g}, 42 \mathrm{mmol})$ and $\operatorname{DMF}\left(30 \mathrm{~cm}^{3}\right)$ was heated for $6 \mathrm{~h}$ under reflux $\left(\sim 155^{\circ} \mathrm{C}\right)$ as described above. After the mixture had been allowed to cool to room temperature, it was treated with $5 \%$ aq. $\mathrm{NaOH}\left(15 \mathrm{~cm}^{3}\right)$, stirred for $20 \mathrm{~min}$, diluted with water $\left(100 \mathrm{~cm}^{3}\right)$ and extracted with diethyl ether $(3 \times 35$ $\left.\mathrm{cm}^{3}\right)$. The combined extracts were dried $\left(\mathrm{Na}_{2} \mathrm{SO}_{4}\right)$ and the benzyl alcohol present was removed by distillation under reduced pressure to leave compound $3 \mathrm{a}(3.6 \mathrm{~g}, 82 \%)$ as a pale yellow liquid (purity $91.5 \%$ by GC) that crystallized with time. The product was recrystallized from $\mathrm{CHCl}_{3}$-hexane to give a white solid, mp $55.6-56.2$ (lit., ${ }^{13 b} \mathrm{mp} 58^{\circ} \mathrm{C}$ ); $\delta_{\mathrm{H}} 3.16$ (dq, $2 \mathrm{H}$, $\left.J_{2,2}, 21.4, J_{1,2}=8.0, J_{1,2}=6.6, \mathrm{CH}_{2}\right), 3.99(\mathrm{dd}, 1 \mathrm{H}, \mathrm{CH})$ and 7.13-7.38 (m, $10 \mathrm{H}, 2 \mathrm{Ph}) ; m / z 207\left(\mathrm{M}^{+}, 18 \%\right), 116(3), 92(7), 91$ $(100), 65(14)$ and $51(5)$.

\section{Benzyl 2,3-diphenylpropionate 3b}

A mixture of $\mathrm{PhCH}_{2} \mathrm{CO}_{2} \mathrm{CH}_{2} \mathrm{Ph}(2.5 \mathrm{~g}, 11 \mathrm{mmol}), \mathrm{DBzlC}(4.0$ g, $16 \mathrm{mmol}), \mathrm{K}_{2} \mathrm{CO}_{3}(3.1 \mathrm{~g}, 22 \mathrm{mmol})$ and $N, N$-diethylformamide $\left(30 \mathrm{~cm}^{3}\right)$ was heated under reflux $\left(\sim 177^{\circ} \mathrm{C}\right)$ for $4.5 \mathrm{~h}$ as described above and then allowed to cool to room temperature. The $\mathrm{K}_{2} \mathrm{CO}_{3}$ was filtered off and the benzyl alcohol present together with the residual reagents were distilled from the reaction mixture under reduced pressure. The residue was purified by gravity column chromatography (gradient elution) 
using light petroleum-diethyl ether $(95: 5, \mathrm{v} / \mathrm{v})$ as eluent to give the title compound $3 \mathbf{b}(2.9 \mathrm{~g}, 83 \%)$ as a pale yellow liquid ${ }^{14 a-c}$ (purity $97.5 \%$ by GC); $\delta_{\mathrm{H}} 3.15$ and 3.44 (dd, $2-\mathrm{H}, J_{2,2}, 13.9, J_{1,2}$ $\left.9.2, J_{1,2}, 6.4, \mathrm{CH}_{2}\right), 3.93$ (dd, 1-H, CH), 4.99 and 5.09 (dd's, 3$\left.\mathrm{H}, J_{3.3}, 12.5, \mathrm{CH}_{2}\right)$ and $7.09-7.34(\mathrm{~m}, 15 \mathrm{H}, 3 \mathrm{Ph}) ; \mathrm{m} / z 316\left(\mathrm{M}^{+}\right.$, $1 \%), 225(6), 181(100), 166(17), 165(18), 91(94), 77(14)$ and 65 (14) (Found: $\mathrm{C}, 84.1 ; \mathrm{H}, 6.35$. Calc. for $\mathrm{C}_{22} \mathrm{H}_{20} \mathrm{O}_{2}: \mathrm{C}, 83.52 ; \mathrm{H}$, $6.37 \%$ ).

\section{Benzylation of phenylacetonitrile under PTC conditions \\ Two procedures were used.}

(a) Liquid-liquid phase-transfer catalysis (LL-PTC; entries 78, Table 2). ${ }^{15}$ A mixture of $\mathrm{PhCH}_{2} \mathrm{CN}(0.70 \mathrm{~g}, 5.98 \mathrm{mmol})$, $\mathrm{PhCH}_{2} \mathrm{Cl}(0.75 \mathrm{~g}, 5.92 \mathrm{mmol})$ and aliquat $336(0.048 \mathrm{~g}, \cong 0.12$ $\mathrm{mmol})$ dissolved in toluene $\left(8 \mathrm{~cm}^{3}\right)$ together with aqueous $\mathrm{KOH}$ $\left(50 \% ; 8 \mathrm{~cm}^{3}\right)$ was stirred at room temperature with monitoring of the reaction by $\mathrm{GC}$.

(b) Solid-liquid phase-transfer catalysis (SL-PTC; entries 7, Table 1). ${ }^{15}$ Three separate mixtures of $\mathrm{PhCH}_{2} \mathrm{CN}(0.50 \mathrm{~g}, 4.27$ $\mathrm{mmol})$, DBzlC $(1.14 \mathrm{~g}, 4.71 \mathrm{mmol})$ and aliquat $336(0.034 \mathrm{~g}$, $\cong 0.084 \mathrm{mmol})$ dissolved in xylene $\left(6 \mathrm{~cm}^{3}\right)$ together with $\mathrm{K}_{2} \mathrm{CO}_{3}$ $(1.18 \mathrm{~g}, 8.53 \mathrm{mmol})$ were stirred at 90,110 and $140^{\circ} \mathrm{C}$, respectively with monitoring of each reaction by GC.

\section{Acknowledgements}

This work was supported by Tessenderlo Chemie, (Belgium): It. Pat. Appl. MI94AN00020 (04/02/1994). Dr A. Bomben is gratefully acknowledged for his help in the synthesis of dibenzyl carbonate.

\section{References}

1 (a) A. C. Cope, H. L. Holmes and H. O. House, Org. React., 1957, 9 , 107 ; (b) W. C. Kenyon, E. M. Kaiser and C. H. Hauser, J. Org. Chem., 1965, 30, 2937; (c) W. C. Kenyon, E. M. Kaiser and C. H. Hauser, J. Org. Chem., 1965, 30, 4135; (d) M. W. Rathke and A. Lindert, J. Am. Chem. Soc., 1971, 93, 2318; (e) D. S. Watt, Tetrahedron Lett., 1974, 707; $(f)$ D. Savoia, C. Trombini and A. Umani-Ronchi, Tetrahedron Lett., 1977,653; (g)A. A. Gevorkyan, P. I. Kazaryan, S. V. Avakyan and Yu. M. Blazhin, Oktrytiya, Izobret., Prom. Obraztsy, Tovarnye Znaki, 1982, 30, 88 (Chem. Abstr., 1983, 98, 53186v), (h) X. Peng, and C. Xu, Huaxue Xuabao, 1983, 41, 514 (Chem. Abstr., 1983, 99, 121779p); (i) K. Sukata, Bull. Chem. Soc. Jpn., 1983, 56, 3306; (j) S. Arseniyadis, K. S. Kyler and D. S. Watt, Org. React., 1984, 31, 1; (k) J. P. Rieu, A. Boucherle, H. Cousse and G. Mouzin, Tetrahedron, 1986, 42, 4095; (l) A. A. Vasil'eval, V. A. Petrosyan, Izv. Akad. Nauk. SSSR, Ser. Khim. 1991, 9, 2160. (Chem. Abstr., 1992, 116, 20750f).

2 (a) M. Makosza, Tetrahedron, 1968, 24, 175; (b) A. Branstrom and U. Junggren, Tetrahedron Lett., 1972, 472; (c) C. M. Starks and

C. Liotta, Phase-Transfer Catalysis, Principles and Techniques,
Academic Press, New York, 1976; ch. 5, p. 170; (d) W. P. Weber and G. W. Gokel, Phase-Transfer Catalysis in Organic Chemistry, Springer Verlag, West Berlin, 1977; (e) E. V. Dehmlov and S. S. Dehmlov, Phase-Transfer Catalysis, Verlag Chemie, Veinheim, 1983 , ch. 3, p. 123.

3 (a) E. M. Kaiser and C. H. Hauser, J. Org. Chem., 1966, 31, 3873; (b) S. Miyano and N. Abe, Chem. Pharm. Bull., 1970, 18, 550; (c) R. Grigg, T. R. B. Mitchell, S. Sutthivaiyakit and N. Tongpenyai, Tetrahedron Lett., 1981, 4107; (d) T. Shono, S. Kashimura and H. Nogusa, J. Org. Chem., 1984, 49, 2043; (e) J. C. Folest, S. Guibe, J. Y. Nedelec and J. Perichon, J. Chem. Res., 1990, $(s), 258 ;(f)$ F. Abe, T. Hayashi and M. Tanaka, Chem. Lett., 1990, 765; (g) M. Tanaka, T. Hayashi and F. Abe, JP 03,246,249, 01 Nov. 1991, Appl. 90/40,238 (Chem. Abstr., 1992, 116, 127822p); (h) M. Tanaka, H. Teruyuki, T. Norio, A. Kazutaka and T. Shinichiro JP 04,290,834, 15 Oct. 1992, Appl. 91/80,829 (Chem. Abstr., 1993, 118, 124185p).

4 (a) P. Tundo, G. Moraglio and F. Trotta, Ind. Eng. Chem. Res., 1989, 28, 881; (b) P. Tundo, F. Trotta and G. Moraglio, J. Chem. Soc., Perkin Trans. I, 1989, 1070.

5 P. Tundo, Continuous Flow Methods In Organic Synthesis, E. Horwood, Chichester, 1991.

6 (a) P. Loosen, P. Tundo and M. Selva, It. Pat. Appl. MI92A00081; (b) P. Loosen, P. Tundo and M. Selva, US Pat. Appl. 922140; Jap. Pat Appl. 4-223302; (c) C. A. Marques, M. Selva and P. Tundo, J. Chem. Soc, Perkin Trans. I, 1994, 1323.

7 P. Tundo, F. Trotta, G. Moraglio and F. Ligorati, Ind. Eng. Chem. Res., 1988, 28, 1565-71.

8 (a) D. Lee and V. Chang, J. Org. Chem., 1978, 43, 1532; (b) M. Shirai and J. Smid, J. Am. Chem. Soc., 1980, 102, 2865; (c) J. M. Harris, N. H. Hudley, T. G. Shannon and E. C. Struck, J. Am. Chem. Soc., $1982,47,4789$

9 (a) D. A. White, Synth. Comm., 1977, 7, 559; (b) N. N. Sukhanov, L. N. Trappel, V. P. Chetverkov and L. A. Yanovskaya, Zh. Org. Khim., 1985, 21, 2503 (Chem. Abstr., 1986, 105, 225743f)

10 V. A. Volkova and D. V. Ioffe, Zh. Org. Khim., 1972, 7, 2177 (Chem. Abstr., 1972, 76, 14048c).

11 (a) G. C. Overberger, L. C. Palmer, B. S. Marks and N. R. Byrd, J. Am. Chem. Soc., 1955, 77, 4100; (b) K. Kondo, N. Sonoda and H. Sakurai, Bull. Chem. Soc. Jpn., 1975, 48, 108; (c) M. Lissel and E. V. Dehmlov, Chem. Ber., 1981, 114, 1210; (d) A-A. G. Shaik and S. Sivaram, Ind. Eng. Chem. Res., 1992, 31, 1167; (e) T. Mizuno, F. Nakamura, Y. Egashira, I. Nishiguchi, T. Hirashima, A. Ogawa, N. Kambe and N. Sonoda, Synthesis, 1989, 636.

12 S. Kim, J. I. Lee and Y. C. Kim, J. Org. Chem., 1985, 50, 560.

13 (a) Dictionary of Org. Compounds, 5th edn., Chapman and Hall, New York, 1982, vol. 1, p. 626; (b) vol. 2, p. 2336.

14 (a) L. I. Smith, C. R. Seances Acad Sci, 1924, 178, 1583 (Chem. Abstr., 1924, 18, 2881 ${ }^{2}$; (b) J. H. Billman and J. L. Rendall, J. Am. Chem. Soc., 1944, 66, 745; (c) R. A. Zingaro, Ethyl Corp. BP. 872,757 Appl. Oct. 30. 1957 (Chem. Abstr., 1962, 56, 7222p).

15 F. Montanari, D. Landini and F. Rolla, Top. Curr. Chem., 1982, 101, 147.

Paper 5/01365H Received 6th March 1995 Accepted 18th April 1995 